\title{
Let's judge a magazine by its cover A textual analysis of the covers of Gadis
}

\author{
SUZIE HANDAJANI
}

\begin{abstract}
In this article, I analyse the covers of Gadis, a magazine for Indonesian teenage girls, from 2009 to 2013. Using textual analysis, I examine these magazine covers as manifestations of local gender ideology amidst pressures from a globalized market. The models on the magazine covers are the embodiment of ideal teenagers and they reflect the magazine's personification of Indonesian adolescents. Images of the models in conjunction with the article titles displayed on the covers construct dominant themes surrounding the lives of female adolescents. In this article, I argue that the dominant gender ideology is perpetuated by the magazine; however, the embodiment of the ideology is shifting from the girly adolescent image to that of a more mature and sophisticated young woman.

KEYWORDS

Teen magazine, gender ideology, magazine cover, female adolescent.
\end{abstract}

\section{YOU CAN TELL A MAGAZINE BY ITS COVER ${ }^{1}$}

Many of the previous research on teen magazines focus on the content by doing an in-depth reading and semiotic interpretation of the text and visual representations. In this article, I examine the covers of Gadis because of several reasons. The first one is the importance of cover to attract potential buyers. It represents the magazine and builds the first impression. Covers can thus be seen as the highlight of the content. Viewing a magazine as a personified entity, the magazine cover is the face which is used to identify the body of the magazine. According to Goon and Craven (2003), the face has become

1 The subtitle is taken from Kelley Massoni, Fashioning teenagers; A cultural history of Seventeen magazine (California: Left Coast Press, 2010), p. 52.

SUZIE HANDAJANI took her PhD from School of Social and Cultural Studies University of Western Australia. Her thesis is entitled "Selling alternative masculinities; Representations of masculinities in Indonesian men's lifestyle magazines". She is currently affiliated to The Graduate School of Gadjah Mada University. Suzie Handajani may be contacted at: suzie_ handajani@yahoo.com.

(C) 2014 Faculty of Humanities, University of Indonesia 
personal and public at the same time. It is personal because it is unique and each magazine has a different face. It is also public because it is always on display for the purpose of identification. Whatever is advertised on the cover may be used as a quick indicator of the personality of the magazine. Covers are important as a signpost to suggest what potential readers may expect in the content. On the news stand, teen magazines are usually sealed with plastic wrap, leaving the covers exposed to help potential buyers decide on whether or not to buy the magazines.

The second reason is the availability of the archives of Gadis' covers from 2009 - 2013. Looking at the images on the covers, it appears, at first glance, that the changes are obvious (see Figure 1). However, both Ferguson and Massoni argue that "everything changes and nothing changes" (Ferguson 1983: 190) and "the more things change, the more they stay the same" (Massoni 2010: 21 and see also Carpenter 1998). Upon closer inspection, these covers perpetuate the same gender ideology in a different packaging. The question is: how is the magazine constructing this different form of packaging? To answer this question, I analyse the text and the models on the covers. The analysis is not meant to be a comprehensive look into the covers, but it is an indicative observation to identify dominant and recurring themes.

I argue that the text on the covers reveals the roles reserved for female adolescents in ways that mirror older women. They are expected to be potential consumers and ideal partners for their boyfriends (perhaps with the prospect of preparing them to become husbands). The dual role in the magazine echoes the dual role of Indonesian women, promoted during the Suharto era as peran ganda. The idea translates into women's role to participate actively in public sphere (which could mean active consumerism) and to be supportive careers in private space. The text on the covers of Gadis suggests a set of roles that are designed to accommodate advertisers and at the same time support the notion of ideal femininities.

The models on the covers portray images of teenage girls who look like the younger versions of their counterparts on the covers of women's magazines. My interest in these models lies in the fact they are represented more as women (albeit young) rather than teenage girls. Female adolescents in the last two years (2012-2013) are represented by older and more mature girls with sultry expressions and more suave poses. There is a transformation from the cheerful and bubbly look to a more poised and cool appearance. This condition corresponds to what other scholars refer to as the sexualization of teenage girls in the media (see Kilbourne and Levin 2008; Newsom 2011). Although these models do not pose in an overtly sexy manner, the transition is representing how teenage girls are constructed this way to accommodate more products: more mature girls need more things to maintain their appearance. 

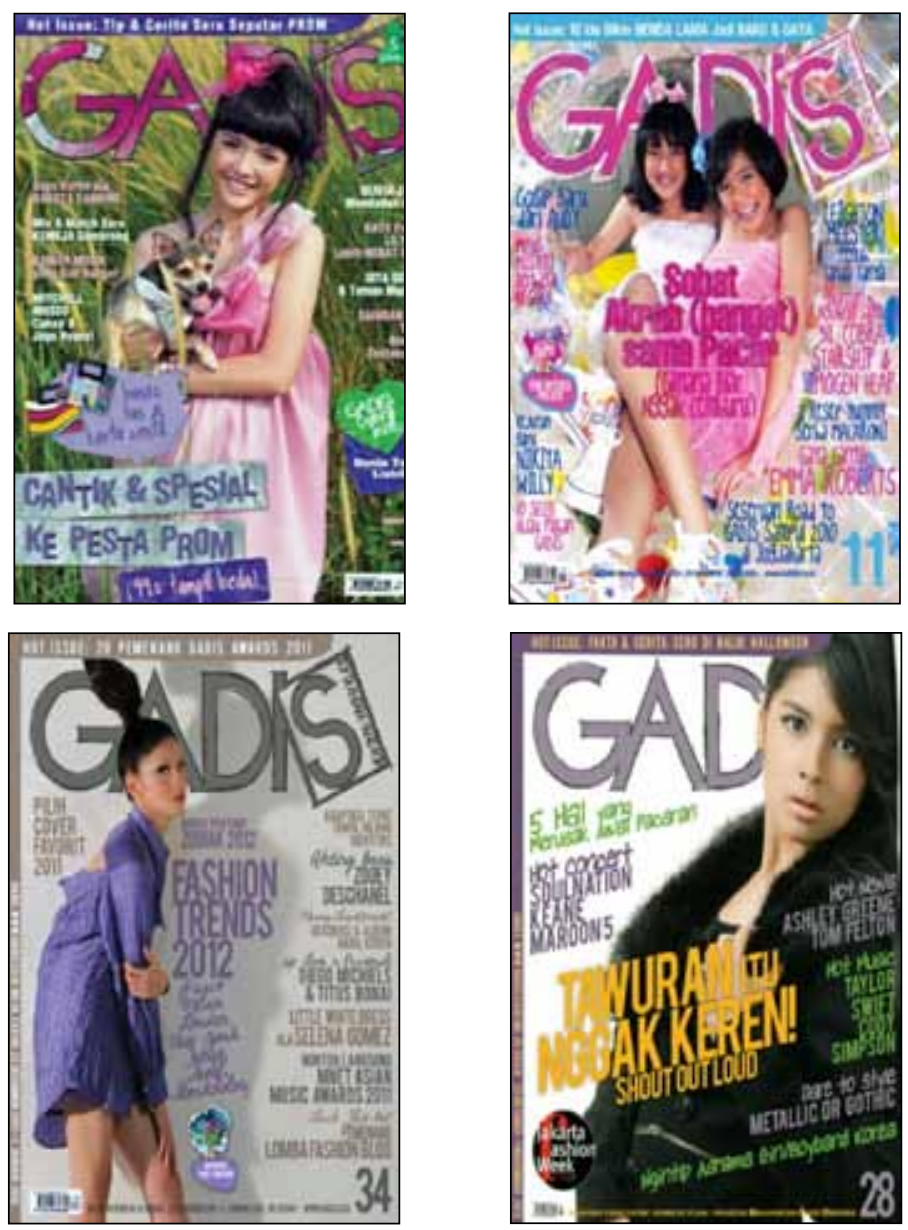

Figure 1. The transformation of the covers of Gadis 2009, 2010, 2011, 2012.

\section{THE SIGNIFICANCE OF GIRLS' MAGAZINES}

As a genre, magazines in general are an important type of media in Indonesia in terms of the amount of advertisements that magazines receive as revenues. ${ }^{2}$ In a later survey, A.C. Nielsen claims that more women read magazines $(52 \%)$ while men read newspapers $(67 \%)$. This is supported by the fact that there are more magazine titles for women and girls than for men and boys. Although the survey also mentions that there is a $50 \%$ increase in internet usage among young people between the ages of $10-19,{ }^{3}$ this does not mean that girls' magazines are losing their charm among teenage girls. Most Indonesian girls' magazines now publish their online issues in addition to hard copies.

2 According to A.C. Nielsen survey in Indonesia; World magazine trends 2001/2002 (http://www.magazineworld.org/assets/downloads/IndonesiaWMT01.pdf), accessed on 2-8-2004.

3 Nielsen Newsletter, Edition 15, 31 March 2011, (http://www.agbnielsen.net/ Uploads/ Indonesia/Nielsen_Newsletter_Mar_2011-Eng.pdf), accessed on 6-3-2013. 
The online version complements the printed editions rather than standing out as a competition.

Teen magazines have been widely researched since they are an important source of information on how teenage girls are socialized into becoming proper women according to the local norms (McRobbie 2000). Content wise, Kelley Massoni observes that girls' magazines usually contain contradicting messages between controlling and flaunting sexuality (2010: 21). The former comes under social and cultural pressures, while the latter is done in accordance with advertisers wish (namely to be sexy is to purchase the right products). Massoni argues that:

The increasing prevalence of beauty and fashion sections in magazines once dedicated to domesticity indicates the growing significance of the body in the late twentieth and early twenty-first centuries. Today women's bodies hold center stage in both service and fashion magazines, advised about and agonized over in articles and advertisements (Massoni 2010: 20).

For a long time, lifestyle magazines have been associated with women's and girls' magazines, while men's periodicals used to be related predominantly with current affair magazines (Ferguson 1983: 2; Wolf 1991: 70). ${ }^{4}$ Although currently there is a number of men's lifestyle magazines in Indonesia, there is always the notion that lifestyle magazines are feminized. This is because of the unique origin of lifestyle magazine as women's or girls' periodicals. The feminization derives from that fact that these lifestyle magazines deal endlessly with appearances, a preoccupation that is frequently associated with the women's realm. Magazines hold a special place in women's realm. In other forms of media, the female section is only allocated in specific parts, such as the women's corner in newspapers or women's programs on television, for instance as soap operas. Unlike other media, women's magazines are completely devoted to women (or appear to). For many women, reading magazines is a way to "connect" and reach out to a wider group of women (Wolf 1991: 70).

In the following section, I will explore how these ideas are incorporated into Gadis and discuss how these concepts are transformed into Gadis' cover designs.

\section{ABOUT GADIS}

Gadis was first published on 19 November 1973. A new issue comes out every ten days. This magazine also claims to be "The first teenage girls magazine in Indonesia since 1973". On the cover of Gadis, there is an additional slogan that says "Paling top di antara yang pop" (The top among the pop). ${ }^{5}$ On earlier

4 However, with the burgeoning of men's lifestyle magazines such Playboy, FHM, Maxim, and Esquire, lifestyle is not the monopoly of women's magazines anymore. The dawn of metro sexuality contributes to the relevance of lifestyle magazines for men.

5 Http://www.Gadis-online.com/majalah.cfm (accessed on 7-4-2003, no longer available). 
magazine covers there are additional slogans: "Bangga jadi cewek" (Proud to be [Indonesian] girls) and "Kita cewek peduli" (We are girls who care). On some of the later editions and on the current website, there is an additional slogan: "Gadis sobat setia kamu" (Gadis is your best friend). ${ }^{6}$ Being the first and the oldest magazine for female teenagers, Gadis becomes a model to be imitated and expanded by other girls' magazines in Indonesia. In the span of thirty years, Gadis has proven its ability to adjust to the fluctuations in market demand and rivalry.

The magazine's title, Gadis 'young lady', was chosen from several possible candidates from local languages in Indonesia with similar denotations: nona (from eastern Indonesia), uni (from West Sumatra), pingkan (from Sulawesi). ${ }^{7}$ Gadis was chosen because it was more widely known in the Indonesian language, and because it is not associated with a particular region, ethnic group, or language in Indonesia. ${ }^{8}$

The choice of magazine title and slogan reflects the notion of constructing female adolescents as members of the Indonesian society. On the covers of Gadis, nationalism and patriotism are often featured in the headlines: "Luv $\mathrm{U}$ Indonesia" $(11,2012)$, "10 things that make us love Indonesia" $(22,2011)$, and " 17 facts that Indonesia is cool " $(22,2012)$. These articles seem to fend off the idea that Indonesian girls are contaminated with western influences which would make them less Indonesian because of the influx of western celebrities featured by the magazine. However, females' participation in public space is gendered. Male citizenship is associated with leadership and oriented to the future. Citizenship for females means that they are seen as the bearers of tradition and culture which are oriented towards preserving the past (Williamson 1986: 106). Preservation and conservation are categorized as a female realm which is reflected with Gadis' headlines on the environment. In 2011 and 2012, the issues frequently feature "Gadis cinta bumi" (Gadis loves the earth) which brings into mind the eco-feminist thinking that aligns females with mother earth.

Information obtained from the on-line edition of the magazine reveals that Gadis" mission is to "inspire Indonesian girls to be always active." ${ }^{\prime 9}$ Gadis declares that it "has always held spectacular events in its effort to scout for 'active girls' we can all be proud of."10 There are three spectacular events mentioned with regards to this scouting effort: Pemilihan Putri Remaja (The Teenage Girl Pageant) in the 70s and 80s, Pemilihan Cowok Sampul (The Coverboy Pageant), and Pemilihan Cewek Sampul (The Covergirl Pageant).

6 Http://www.Gadis.co.id/sejarah (accessed on 6-3-2013).

7 Http://www.Gadis.co.id/sejarah (accessed on 6-3-2013).

8 Tapi akhirnya dipilih GADIS, karena dianggap lebih netral. (Http://www.Gadis.co.id/ sejarahaccessed on 6-3-2013)

$9 \quad$ [...]GADIS ingin memberi inspirasi buat cewek-cewek Indonesia untuk selalu aktif. (Http:/ / www.Gadis-online.com/majalah.cfm, accessed on 7-4-2003, no longer available).

10 GADIS selalu punya acara seru yang mampu menghasilkan cewek-cewek aktif yang bisa dibanggakan. (Http://www.Gadis-online.com/majalah.cfm, accessed on 7-4-2003, no longer available.) 
The magazine mentions several names of individuals in its profile, all of whom were winners and runners-up for mentioned events, and who are now celebrities in the entertainment business as models, actresses, singers, and a writer (who is also an ex-model). There are only two names included in the magazine's profile who are not entertainers. One of them is the cover girl for the first edition of the magazine, who was a drum majorette from Tarakanita (an all girls popular private high school) in Jakarta. The other one is said to be a career woman, even though she started off as a model. Despite clear evidence that these events and contests will eventually lead the contestants and winners to the entertainment business (even the drum majorette brings out the notion of a celebrity in a smaller scope). Gadis claims that these events have discovered the "multi talents" these young girls have. ${ }^{11}$ This implies the limitation of the meaning of the word "talent" that covers only the activity and the capacity to perform and entertain other people. Fame and popularity achieved by winners of these events and their success in the entertainment industry seem to legitimize the positioning of female adolescents as objects of spectacle. This consequently leads to the perception of the importance of looks as assets for girls to gain acceptance from the public.

According to Petty Siti Fatima, Editor-in-Chief of Gadis for fourteen years:

Readers of Gadis are teenagers who live in big cities, who are also exposed to developments in technology, smart, active, stylish, and love music. But teen readers are not loyal readers. If they think that Gadis does not represent their taste, they are bound to go away. Moreover, there are many teen magazines these days. They have a lot of options. ${ }^{12}$

Gadis has managed to survive for thirty years despite the cut-throat competition from other teen magazines. The magazine claims it is due to their knowledge of the characteristics of middle- to upper-class teenagers, and the way they steer editorial policy. This is also what they are selling to the advertisers, claiming that, "we are the first very best, so we are the best" (Clara 2001). ${ }^{13}$ I assume that other female teen magazines learned a great deal from Gadis in terms of reading and inventing teen demands and also in formatting the magazines' layout, although currently Indonesian female teen magazines also follow trends from their western counterparts.

Gadis is published as the sister company of a renowned Indonesian women's magazine, Femina. Like Gadis, Femina is also the first and leading popular Indonesian women's magazine. They are both published by PT Gaya Favorit Press owned by Sofjan Alisjahbana, the son of the great Indonesian

11 Dariajang ini banyak sekali muncul cewek-cewek multi bakat. (Http://www.Gadis-online. com/majalah.cfm, accessed on 7-4-2003, no longer available. See also http:/ / www.Gadis.co.id/ sejarah/4, accessed on 6-4-2013.)

12 Pembaca Gadis adalah remaja yang tinggal di kota-kota besar, juga sangat terbuka terhadap perkembangan teknologi, pandai aktif, gaya, dan senang musik. Tapi, pembaca remaja bukan pembaca setia. Kalau Gadis dianggap tak lagi mewakili selera mereka pasti ditinggalkan. Terlebih lagi, banyak majalah remaja yang beredar saat ini. Mereka banyak pilihan (Clara 2001).

13 English words original. 
writer Sutan Takdir Alisjahbana. Sofjan Alisjahbana's wife, Pia Alisjahbana, is the editor of both Gadis and Femina. Considering that she is the editor of both magazines, we can expect that Pia Alisjahbana's influence in Femina could also be seen in Gadis. According to Suzy Azeharie in her research on Femina, despite its modern approach to women, Femina still upholds the conventional roles of virtuous and angelic women in society: that of a wife and mother (1997: 136-141). Furthermore, three names that Suzy Azeharie mentions as the founders of Femina are also on the board of directors of Gadis: Mirta Kartohadiprodjo, Widarti Gunawan, and Pia Alisjahbana (1997: 136).

Ria Clara argues that Gadis does not draw a clear line between content and advertisement, which is one of the basic principles in journalism (2001: 30-33). Gadis cannot overlook the fact that advertisements are the main source of revenue because readership itself cannot support the magazines financially. This is why the magazine has incorporated entertaining and educating aspects into the magazines, such as "School is cool" $(19,2013)$, "Scholarship information" $(09,2013)$, " 3 cool hairstyles for school" $(19,2013)$, in order to attract both readers and advertisers. However, Ria Clara concludes that this is a common occurrence with the media whose content is, to a certain extent, dictated by sponsors.

\section{COVERS OF GADIS; SOMETHING OLD}

One headline that keeps appearing on the covers of Gadis from 2009 to 2013 is the boyfriend issues and how to maintain the relationship with him. Each year, there are only several editions without any relationship taglines on the covers. Below are some of the samples from each year:

Never had a boyfriend. Is that normal? $(14,2009)$

How to fight nicely with your boyfriend $(07,2010)$

How to differentiate the bad guys from the good guys $(21,2011)$

How to detect when your boyfriend is lying $(04,2012)$

Elegant ways to make a guy declare his love for you $(06,2013)$

The tone of this kind of article is typical in female magazines where relationships are seen as central to a woman's live. Men's lifestyle magazines may have some articles on relationships (Handajani 2010), however, only female magazines agonize so much over them. Females are meant to take care of others, including making sure that a relationship runs smoothly. In one issue of Gadis, there was even an article advertised on the cover on how to make your boyfriend get along with your mother (Tip mendekatkan pacar sama mama). ${ }^{14}$

Not just with boyfriends, but getting along with other members of the family, particularly parents, is also perceived as a girl's duty, as indicated by the following titles: "Why parents rarely apologize" $(15,2009)$, "How to deal with family issues" (06, 2012), "Family ties" $(02,2012)$, "How to ask 
questions about sex to your parents" $(13,2011)$, "Family gathering is fun" $(23,2011)$, "My mom, my idol" $(13,2011)$. This foresees teenage girls' role as the person who should keep the family together. When a family breaks up, like in divorce cases, it is so easy to say that the woman is not doing a good job in keeping her family intact. When parents do get divorce, daughters are expected to be wiser in dealing with the separation: "No need to get upset over your parents' divorce" $(05,2010)$.

In female magazines, the discourse surrounding relationships is one of giving and caring, whereas in men's lifestyle magazines, the discourse on relationships is one of conquest (Handajani 2010). Overall, the headlines regarding relationships evolve around getting a boyfriend and keeping him. Articles, such as "Beware of boyfriend snatchers", "Are you the victim or the perpetrator?" $(08,2012)$ and "How to deal with a wild boyfriend" $(19,2011)$ are further evidence of this.

One way to get and keep a boyfriend is to maintain an attractive appearance. This dovetails perfectly with headlines on fashion and lifestyle. Any event is turned into an opportunity to look cool such as "Countdown to prom party" (13, 2013), "Enjoy holiday" $(16,2011)$, "Back to school" (19, 2013), and "Valentine's day" (04, 2012). Every year these topics are recycled accordingly. These articles advertised on the covers are reviewing the same topics in seemingly different ways. Every year, groups of teen girls go through the same excitement, or anxiety, when they start school, go for a holiday, celebrate Valentine's Day, and attend prom.

Although this article is on female teen magazines, it is necessary to position it within the wider body of research on women's magazines. This is due not only to the fact that most of the discussions on female magazines is focused on women rather than on female adolescents, but also to the fact that gender relations in society cut across generations. This puts female adolescents in the same gender position as women, although in a modified form due to the differences in age and generation.

The recycling of articles in Gadis marks the recurring anxieties in teenage girls' lives. They are taught to be constantly aware that in any public space, such as proms, school, or Valentine's Day parties, girls are judged by their appearances. Most of these events call for the celebration of carefree youth and innocent fun. However, the carefreeness often gives way to tensions since girls are taught at such a young age that their rivals and enemies are other girls (see Oakes-Ash 2003). The competition evolves around the search and acknowledgement for the prettiest, sexiest, most stylish, and other visible categories.

Every girl is a judge to other girls. The covers reveal this with titles such as, "Wanted: The real diva" $(08,2013)$ and another regular feature on the cover: "Pemilihan Gadis Sampul" (Cover girl pageant). The pageant is a real competition but it also reflects the kind of competition that teenage girls have to go through on a daily basis. This kind of pageant sends the message that girls who belong to the "in" crowd are those who are above the average 
standard in terms of physical attractiveness.

The irony of this is that women are seen as forming a sisterhood with other women while, at the same time, they are getting themselves into fierce competitions with other groups of women. Teenage girls are introduced to this paradox early in their lives as indicated on the covers: "What a friendship" $(03,2013)$, "Best friend's rules" $(02,2012)$, "Be my friend; The importance of friendship" $(03,2010)$, and "How to be friends with your seniors" $(23,2010)$. They need to form good relationships with other girls in order to form alliances against rivalling groups. The American coming of age movie "Mean girls" is an iconic portrayal of this.

Headlines on the covers provide strategies and guides for girls to survive their hectic social lives and get along with other girls. Some of the tips are about manners and politeness, which remind us of middle class and gentrified comportment, such as: "Stop talking about people behind their back" $(07,2012)$, "Pay attention when people talk to you" $(25,2012)$, "Learn the survival guide to be the new kid from movies" $(18,2013)$, and "You = your social media status; How to read characters through social media" $(18,2013)$, "Wanted: the right image" $(03,2012)$, "Tweet War; How important is it?" (22, 2012), "The importance of first impression in a new place" $(18,2012)$, "Tips on how to deal with different types of seniors" $(28,2012)$. The impression is that females should be the one that understand others and take care of other people's feelings, and care what other people think of them. This often results in teenagers being self-conscious about their appearances and performances in public places where they feel they are constantly judged from their look (see Berg 2009).

Furthermore, the magazine always sends messages of aspirations on the covers. These messages are supposed to reach out to girl readers in order to boost their self-esteem. Some of the pep-lines are: "The power of you; Yes, it's about girl power" $(10,2013)$, "There is a star in you" $(22,2013)$, "Beauty is you" (14, 2012), "You're so beautiful" $(07,2011)$, "Beauty = Loving yourself" $(06,2010)$. The problem with these lines is that they are emblazoned next to a beautiful model on the magazine covers. The juxtaposition seems to formulate a different message altogether. It is like saying, "Yes, you are beautiful, but only if you try to make yourself look like her." It is accepted that girls who appear on the covers are supposed to be role models for the girl readers. However, the role models do not represent the range of varieties of the readers. These models predominantly have sleek hair, light and smooth skin, slim built, and dressed in stylish designer outfits, which many of the readers may not have.

This is then the cue for all sorts of beautifying products and tips, to make their announcements on the cover: "Pick the right outfits for your hangouts" $(24,2012)$, "Look beautiful with a bun hair-do" $(25,2011)$, "Coolest accessories" $(29,2011)$, "Six must-have fashion items" $(30,2010)$. Even without these titles on the cover, the models' wardrobe and make-up speak for themselves: that these are the things the readers must purchase and do in order to achieve the standard of ideal beauty. Celebrities mentioned and shown on the covers 
function as role models who set the benchmark. Knowing which celebrities to be followed and to aspire to is part of the knowledge that determines whether or not a teenage girl is savvy in her teen pop culture world.

The whole purpose of girls' magazines is about creating heterosexual young women who require the male gaze to sanction their performance and appearance. The male gaze, to a certain extent, helps create female magazines to become showcases of attractive women who serve as examples to female readers. The term "male gaze", coined by Laura Mulvey, is used to denote the way males look at and perceive things (1975). It is also used by film critics to suggest male voyeurism and fetishism in making movies that put women as the object of attention (Chandler 2004). The term has now been extended outside movies to include media coverage generally. Female magazines are not free from the male gaze. The idea that women should "look pretty" under all conditions, for example, is a male ideology (Massoni 2004: 47-64). Suggestions on how to stay beautiful in the magazines are actually suggestions for how to entertain the male gaze itself.

Most researchers are concerned with the way the media shows a preference for and idolizes certain types of female representation. What most researches have in common is the finding that the representation of women in the media, and in female magazines in particular, is not empowering for women. This has not changed over time despite differences in research period. The most frequent example cited in this kind of research is the predictable and static female aesthetics over the decade: tall, thin, light skinned, preferably from mixed western-Indonesian parentage (Handajani 2005). This is not empowering since the standard does not acknowledge different shapes, sizes, skin colours, and cultural origins of different Indonesian females. In my Gadis samples, this standard still prevails. Advertisements for skin lightening such as Pond's White Beauty ${ }^{15}$ testify to the persistence of the white hegemony. The condition is exacerbated even more by the increasing presence of foreign celebrities who are represented monolithically as "naturally" light skinned, tall, and skinny. They are one-hundred percent Anglo-Saxon (as opposed to mixed-blood Indonesians) who embody the notion of the admired west and modernity.

Recurring taglines on the covers about how to keep up appearances, and about grooming are suggestive of the feminine cycle as exemplified by the headlines of the covers: "How to treat your own face and nails" $(12,2012)$, "Express yourself with the colour of your lipstick" $(32,2012)$. Women are taught that they have to do their make-up and treat their face, hair, and body in a consistent manner with regular frequency. This is supplied by Gadis with annual updates, such as "Guide to beauty 2013". At the end of every year, there is always a forecast on fashion trends for the following year.

Despite updates from time to time, fashion and trend does not encourage major changes from time to time. The main routine remains the same. Following Judith Butler's argument (1990: 145), this repetitive action makes 
females become women. Cosmetics and fashion pages show that being a female is not enough: she has to perform like one. Susan Bordo comments on how:

we are surrounded by homogenizing and normalizing images - images whose content is far from arbitrary, but is instead suffused with the dominance of gendered, racial, class and other cultural iconography (Bordo 1993: 250).

According to Ferguson (1983: 2), femininity is always under construction while masculinity is not. Masculinity is seen as perfect, while femininity is always in progress. Male magazines do not dwell forever on teaching men about their masculinity. They come in more varieties (Ferguson 1983: 2; Wolf 1991: 2). Information provided in current affair periodicals for males improves and nourishes their quality as human beings as a whole and not just as males per se. Women's magazines, on the other hand, are mostly about their femininity. Men's lifestyle magazines celebrate men's masculinity, while women's lifestyle magazines lament the imperfections of femininity (not pretty, slim, and stylish enough). Ferguson argues that:

There is no men's periodical press in the same generic sense that there is for women. Men's magazines are aimed at particular groups of males and cater for parts of man's life - his business, hobby or sporting interest - not for the totality of his masculinity, nor his male role as such. This difference in audience approaches seems to rest on an implicit assumption shared between editors and publishers that a female sex which is at best unconfident, and at worst incompetent, "needs" or "wants" to be instructed, rehearsed, or brought up to date on the arts and skills of femininity, while a more powerful and confident male sex already "knows" everything there is to know about the business of being masculine (Ferguson 1983: 2).

Ferguson implies from the above quote that masculinity is perceived as already perfect. Femininity on the other hand is not. Being a proper female is based upon correct practice or performance of femininity, and the male gaze is the judge of this performance. Female magazines are treated as a special genre for a special gender: female, which is a deviant gender that is "not male" (Ballaster 1991: 10-11). Through their magazines, women can improve and nourish their quality as women. This is supported by the large numbers of "How to" articles which are typical of girls' magazines.

Joanne Hollows is another writer who has pointed out that other media, such as television, also reflect this feminine cycle when catering to their female audience:

[Just] as the classic realist text relates to the goal-oriented nature of men's work, so there is a unique fit between the structure of soap opera and women's work in the home. Soap opera emphasizes repetition, lack of progress or end and connection to others, all of which characterise women's work at home (Hollows 2000: 96).

Within general media, such as newspaper or television, once a column or a 
program is targeted specifically at women, it is trivialized (Tuchman 1978: 8). It is seen as a smaller, insignificant segment within a bigger and dominant medium. The term "chick lit", for example, may derive its condescending connotation from the level of predictability of plot or the fact that they just deal mostly with relationships and romance. As I mentioned above, the covers of Gadis similarly are filled with snippets of tips on relationships and romance, such as " 5 things that ruin the start of your relationships" $(28,2012)$, " 7 ways to forget your ex" $(24,2011)$, "The right time to say I love you" $(10,2010)$, "How to make over your boyfriend and turn him stylish" $(29,2012)$. This implies the central role of romance and having a boyfriend in a girl's life.

In addition to chick-lit, a new genre has emerged on the covers of Gadis: horror movies and articles on supernatural beings and haunted places. I do not claim that the interest in horror movies and love for haunted places is a typical female past time. However, I have not found similar in intensity in other boys' and men's lifestyle magazines. This easily brings to mind the gender divide between male/female and rational/irrational. Supernatural phenomenon is a new popular genre on Indonesian television judging from the growing number of similar programs in different stations. The trend catches on as displayed on the covers: "The mysterious ghost in school" (18, 2012), "The mystery of the haunted playground" $(12,2011)$, "The mystery of seance" $(13,2011)$, "The ghost under the bed" $(11,2011)$, "The mystery of the ugly ghost" $(08,2011)$, "Ghosts of celebrity houses" $(06,2012)$, and the list of titles go on for two years in 2011 and 2012.

For teen girls in their own private circle, the girls' magazines are all they have in which what they do is taken seriously - or at least they think so. The magazines address girls' need to be understood and even glorified by their peers. They hold a special niche in the female world because they seem to cater to females' need (Faludi 1992). Female magazines are one medium that addresses females and female paraphernalia (fashion, household, relationships, and horror movies) as significant and not marginalized. Female magazines put females at the centre of attention and for a moment, suspend the idea that women are marginalized in a male-dominated world. Wolf says that:

Women are deeply affected by what their magazines tell them (or what they believe they tell them) because they are all most women have as a window on their own mass sensibility (Wolf 1991: 70).

Female magazines build a sense of bonding among the female gender. The content is mostly presented in a friendly tone, like the tone of a peer (Ballaster 1991: 9). This usually involves the colloquial use of language, slang, and the sentences are usually scattered with English words:

"Ngadepin pacar bandel" (Dealing with unruly boyfriend) (20, 2011),

"Boy oh boy. Semua tentang cowok" (Boy oh boy. All about guys) $(14,2011)$, and

"Tawuran itu nggak keren; Shout out loud" (Fighting is not cool; Shout it out loud) $(19,2012)$. 
The language is sometimes written as it is spoken, with grammar inconsistencies, gaps between speeches and so on. This method is an effort to unite females from different class backgrounds, giving them a sense of shared identity (Ballaster 1991: 9). It is a way of invoking a sense of equality because, according to Kress, "speech is closer to solidarity, writing is closer to power." (Kress 1988: 97). This sort of intimacy is what is needed to bring the readers together in one big group, able to share in a common female culture, although rivalries and catfights loom large at the back of these girls' minds. Boys' magazine, like Hai, also employs colloquial language in the content. However, male bonding in Hai is not the same as in girls' magazines. Male magazines affect males differently because other media in society are predominantly presented from males' point of view.

Current affairs magazines, such as Time and Newsweek, are often seen as male magazines, in contrast with female magazines which are considered to be full of "chit chat". Time and Newsweek are regarded as adopting a male point of view. In these magazines, the formal and standard language used implies the seriousness of the "male issues" under review and evokes images of men discussing issues of world importance. I collected some popular men's magazines, such as Maxim and FHM, and observed that they do not use formal language. However, I think their informality is to emphasize leisure rather than male bonding.

Male special interest magazines are just a small fraction of the whole media. Although male magazines, such as $F H M$, could qualify as light entertainment equal to female magazines, men have other serious media to turn to, such as television and newspapers. The mass media are "men's" media in the sense that they are controlled and constructed by an ideology that is predominantly male (Ibrahim, Subandy, and Suranto 1998: xi-xii). A large portion of the media is not specifically identified as male media, but most adopt the male gaze and male point of view. This male point of view is then expanded to represent both genders and this shows male domination in public discourse.

Most male magazines tend to specialize in one area, such as politics, finance, economics, science, or computers. Female magazines do not specialize in any single form of interest, hobby, or profession. When they do specialize, it is still within the female zone, branching out to an even more specialist femininity: for instance, now there are bridal, cooking, hair, make-up, and haute couture magazines. They are miscellaneous, but still within a massive collage of femininity. This implies that women are not meant to specialize in any areas in particular apart from being women.

Females, having been under construction ever since they were born, are in a way "stunted" in their development as a person in public space, because they are taught how to be females rather than to be individuals. Female magazines are complicit in this process. As Angela McRobbie argues:

[T] heir [females'] immersion in what seems to be an overwhelmingly conservative, and traditionally female kind of culture is not simply a matter of choice. The girls have been directed towards this from early childhood (McRobbie 2000: 50). 
As a comparison, McRobbie further remarks that:

Sociologists looking at male youth groupings normally expect, for example, to find certain clearly visible features such as orientation towards football, motorbikes, fishing - even vandalism, or violence. But with girls there existed no such focus (McRobbie 2000: 45).

This acknowledgement that females' activities are generic and never specific brings with it a message that males are meant to have a career or a profession. They are constructed to be universal power holders. Females, on the other hand, are not meant to specialize in anything other than being attractive. Even their articles on aspiration and in boosting girls' self-esteem are still reliant on the power of good looks, such as " 10 beautiful and inspiring celebrities" (10, 2011). In a different issue at the top of the cover the line says, "It is important to dig your potential" $(10,2013)$ and then several lines below there is, "Form available for Cover Girls Competition" (10, 2013). So, digging for potentials does not depart very far from good looks. It is similar with an optimistic title on one issue, "Yes, target accomplished; Here is the secret" $(12,2013)$ which implies that girls should work hard for their achievements. However, it is juxtaposed next to a long legged girl in shorts, with shining long hair that seems to pose a life of leisure. It is not the image of working hard. It is difficult to conjure images of hard work and effort when the models available are posing vulnerable beauty which would melt and fade with the notion of the slightest physical activities.

\section{THE DISAPPEARING OF THE SMILES; SOMETHING NEW}

Most of the poses of the models on the covers are devoid of movements or actions. The poses very often do not suggest that the girls are in middle of any activities other than maintaining a pose. This is different from males when they are put on covers of men's or boys' magazines. They are often portrayed in the middle of doing something where their body language suggests actions. It would be an oversimplification to suggest that this is reminiscent of the supposedly passive nature of girls and the activeness of boys. However, it does reflect the construction of the elite middle class Indonesian women which maintains that elite women do not work hence do not involve themselves in physically exerting activities. These ideals are taken mostly from Javanese courtly behaviour which dictates that upper class women should maintain their poised and dignified look. This, in turn, was mostly adopted during the Dutch feudalism (Robinson 2009: 40).

Additionally, I observe that although the gendered ideology of innocent carefreeness within the content of Gadis remains largely the same, there is a change in the visual representations of adolescents on the magazine covers from 2011-2012 (see figure 1) in which they rarely smile anymore. Within this period, female adolescents appear on the covers with more serene expressions that were not present in earlier issues. There is a sense of less cuteness and fiercer looks on the expressions of the teen models. In contrast, covers of 
earlier issues from 2009-2010 are simply flowing with bubbly teenagers with extremely white and wide toothy smiles. The smile which used to be the mark of innocence is now wiped off the models face, to be replaced with slight leering and just a stretch of the lips. Gone are the sprightly images of teenage girls from the covers of Gadis from 2009. These girls have grown up to become young women.

These covers with disappearing smiles provide some evidence to the concerns from other researchers such as Berg (2009), Kilbourne and Levin (2008), and Newsom (2011) that teenage girls in the media are rushed to grow up to become women so that they would add to the cohort of female consumers of beauty products and fashion. Brumberg (1997) mentions that young girls are undergoing physical changes faster than the previous generation because now they have earlier menarche. However, the shifting representations of teenage girls who look like the miniature versions of older women in the media are more worrying. They are the result of marketing ploys to create the needs to look like older women who require a complete set of make-up and a wide range of wardrobe choice. The irony in this is that as these girls get older they will reach a point where they are bombarded with products from advertisements to make them look younger.

\section{CLOSING REMARKS}

Female magazines could be said to be a reflection of a woman's life. There is a sense of routine when observing the cyclical nature of the headlines on the magazine cover of Gadis. Teenage girls have to constantly update their wardrobe, do their hair, put on a touch of make-up, look nice, and do not forget to take care of their boyfriends.

In this respect it is parallel with the fact that women's lives are cyclical, both biologically and socially. They involve the female cycles of menstruation, pregnancy, labour, and lactation, and then it is back to menstruation again. The social reproduction work of women involves endless house chores and childcare (Firestone 1997: 19-26). Even looking beautiful is seen as a woman duty to keep her man. Teen magazines reflect this aspect of femininity by romanticizing domestic relationships. They may not romanticize menstruation, pregnancy, and lactation, but the magazines do laud the ability of teen girls to prepare their status as the person with duty of care within the family.

Teen magazines are both a catalogue of pop culture and a glossary of teen culture. By buying the magazines, teen readers are consuming images and ideas. These images and ideas are not only informative but also persuasive. Stivens says that one of the old feminist criticisms is that the mainstream is male stream (Stivens 1998: 3). Even women's magazines are produced under this male stream, by either male producers or female producers who espouse male ideology. Gadis, in this case, is romanticizing teenage girls' roles by turning beauty routines into a right. In truth, older women realize that they are expected or even obliged to look a certain way to comply with the conventions of female aesthetics. Eventually this aesthetics endeavour is 
to satisfy their male partners. Gadis realizes this by making the boyfriendgirlfriend relationships a significant part of teenage lives. It marks their entrance into adulthood and signals a tacit acknowledgement that a girl's beauty has at least one official admirer: her boyfriend.

\section{REFERENCES}

Azeharie, Suzy. 1997. "Representations of women in Femina; An Indonesian women's magazine." Master thesis, Murdoch University, Western Australia.

Ballaster, Ros et al. 1991. Women's worlds; Ideology, femininity, and women's magazines. London: Macmillan.

Berg, Barbara, J. 2009. Sexism in America; Alive and well and ruining our future. Chicago: Lawrence Hill Books.

Bordo, Susan. 1993. The unbearable weight; Feminism western culture and the body. Berkeley: University of California Press.

Butler, Judith. 1990. Gender trouble; Feminism and the subversion of identity. London/New York: Routledge.

Brumberg, Joan Jacobs. 1997. The body project; An intimate history of American girls. New York: Random House.

Carpenter, Laura M. 1998. "From girls into women; Scripts for sexuality and romance in Seventeen magazine, 1974-1994", The Journal of Sex Research 35(2): 158-168.

Chandler, David. 2004. "Laura Mulvey on film spectatorship", Notes on 'The Gaze'. [Http://www.aber.ac.uk/media/Documents/gaze/gaze09.html, accessed on 28-9-2004.]

Clara, Ria. 2001. "Liku-liku dunia remaja”, Pantau; Kajian Media dan Jurnalisme II(019): 30-33. [Http:// www.pantau.or.id/txt/19/12.html, accessed on 3-4-2003, no longer available.]

Faludi, Susan. 1992. Backlash; The undeclared war against women. London: Chatto and Windus. [First edition 1991.]

Ferguson, Marjorie. 1983. Forever feminine; Women's magazines and the cult of femininity. London: Heinemann Educational Books.

Firestone, Shulamith. 1997. "The dialectic of sex", in: Linda Nicholson (ed.), The second wave; A reader in feminist theory, pp. 19-26. New York; London: Routledge.

Gadis [Http:/ / www.Gadis.co.id/majalah], accessed on 6-12-2012.

Goon, Patricia and Allison Craven. 2003. "Whose debt? Globalization and white facing in Asia", Intersection; Gender, History and Culture in the Asian Context, Issue 9 (August). [Http://www.she.murdoch.edu.au/ intersections/issue9/gooncraven.html, accessed on 6-5-2004.]

Handajani, Suzie. 2005. "Globalizing local girls; The representation of adolescents in Indonesian teen magazines". Master thesis, University of Western Australia.

Handajani, Suzie. 2010. Selling alternative masculinities; Representations of men in Indonesian lifestyle magazines. Phd thesis, University of Western Australia. 
Hollows, Joanne. 2000. Feminism, femininity, and popular culture. Manchester; New York: Manchester University Press.

Ibrahim, Idi Subandy, and Hanif Suranto (eds). 1998. Wanita dan media; Konstruksi ideologi gender dalam ruang publik Orde Baru. Bandung: Remaja Rosdakarya.

Kilbourne, J. and D.E. Levin. 2008. So sexy so soon; The new sexualized childhood and what parents can do to protect their kids. New York: Ballantine Books.

Kress, Gunther. 1988. Communication and culture; An introduction. Kensington, NSW: New South Wales University Press.

Massoni, Kelley. 2004. "Modelling work; Occupational messages in Seventeen magazine", Gender and Society 18(1): 47-65.

Massoni, Kelley. 2010. Fashioning teenagers; A cultural history of "Seventeen" magazine. California: Left Coast Press.

McRobbie, Angela. 2000. Feminism and youth culture. Basingstoke: Macmillan.

Mulvey, Laura. 1975. "Visual pleasure and narrative cinema", Screen 16(3): 6-18.

Newsom, Jennifer Siebel. 2011. Miss representation. [Http://www.youtube. $\mathrm{com} /$ watch? $\mathrm{v}=\mathrm{TyC} 2 \mathrm{iWrSYJ8}$, accessed on 16-8-2013.]

Oakes-Ash, Rachael. 2003. Anything she can do I can do better; The truth about female competition. Sydney: Random House.

Robinson, Kathryn. 2009. Gender, Islam, and democracy in Indonesia. New York: Routledge.

Stivens, Maila. 1998. "Pemikiran tentang gender, civil society, dan negara di Indonesia", in: Ibrahim, Idi Subandy, and Hanif Suranto (eds), Wanita dan media; Konstruksi ideologi gender dalam ruang publik Orde Baru, n.p. Bandung: Remaja Rosdakarya.

Tuchman, Gaye. 1978. Making news. New York: Free Press

Williamson, Judith. 1986. Consuming passions; The dynamics of popular culture. London; New York: M. Boyars.

Wolf, Naomi. 1991. The beauty myth. New York: William Morrow. 